\title{
Understanding Why There Is Skepticism on Covid-19 Precautionary Norms in India
}

\author{
Gautam Kr Ghosh* \\ Ph.D. in sociology \& PG in Management of Reproductive and Child Health, Research scientist with ICMR National Institute of Cholera and Enteric Diseases, \\ ratna, Kolkata, India
}

Submission: August 15, 2020; Published: September 09, 2020

*Corresponding author: Dr.Gautam KrGhosh, 20/1B Lalbazar Street, Kolkata 700001, West Bengal, India, Cell:+91 9831024847,

E-Mail:gautamkghosh@hotmail.com

Keywords: Socio-cultural; Coronavirus; Health-communications; COVID-19; Governance; Business continuity; Administration

\section{Opinion}

In midst of dreaded Coronavirus infection surge, reports in the media indicated people in droves, with scant respect for distancing rules, thronged the markets, shops, malls and eateries. Many ventured without mask in public places. Large number of crowded public transport, and two and more people travelling in two-heelers became a common site across Indian major cities. More and more, young and middle-aged, people reportedly fell prey to the infection and some unknowingly got infected and cured, already. While generally, there existed a high level of compliance among people by wearing masks in public, and generally trying to keep their distance from other people, yet, in some containment zones, people are reportedly ignoring Covid-19 precautions. Irrational as this may seem, health-communications experts say denial is a natural human response to overwhelming emotion and panic. It is so natural that even trained physicians have questioned the outbreak. Human nature is enigmatic especially when there is no dearth of information on different media- accessible to allabout the need to be on guard. Yet it is not entirely that habit alone accounts for the disparagement of mask-wearing and not caring to maintain safe distance at public spaces. Understanding their behavior and revising strategies for community engagement at local level enhancing their adherence to safety precautions can be achieved. Interfaces with experts and social activists, led to the understanding of three intersecting trends here that underlie the beliefs of a lot of COVID-19 skeptics based on socio-cultural dynamics.

Trust deficit: Can lead people to question whether the recommendations made by those experts are truly so important. A recent Gallup study on finding people's perspectives on whether the rapid spread of Coronavirus has in some way shaken their trust in established Institutions, found that the answers from those affected by individual or near one's Covid-19 infection had certain bearings. Those affected directly or indirectly, indicated 10 percent decrease in their trust on Institutions; and 5 percent on Government. There can be various reasons for the trust deficit that may include the following: (1) Insufficiency in sustained community engagement and communication at the local level ; (2) Citizen's relative lack of confidence in the administrative capabilities, impartial and efficiency often shaped by partnership, access to reliable information (countering fake social media news) and past interactions with authorities; (3) Lack in building people's trust in science and their confidence in cumulative body of research findings; with the flow of credible information and accountability;(4) skepticism towards Covid-19 policies is also pronounced in places where elections are on the horizon, and use of ambiguity and weasel words in promises during election time done. More instances can be cited by others on this score. Trust is critical to large-scale citizen compliance and strengthening it will require a range of interventions in fast-moving pandemic situation.

Abstraction: It is another causative factor influencing individuals' activities, as the immediate results of the pandemic are not up front for some individuals. They may find out about cases in the news, however they may not know anybody legitimately who has become ill or passed on from the infection. At the point when one is at far off from things in time or space, at that point one considers them conceptually. All things considered, pondering a general idea, for example, illness doesn't expect one to consider what it resembles to be not able to get breath since one's lungs are loaded up with liquid, and to be experiencing 
the torment of high fever. Once more, individuals will in general feel the fatigue and disappointment of being socially disengaged, danger of losing positions and openings. They feel the discomfort of having to wear masks in public and disappointment of missing out on sporting events, concerts, and movies. Those consequences of social distancing may feel more real than the pandemic. And so, when people do a cost-benefit analysis, they may decide that the costs of social distancing are not worth the benefits of decreasing what they already see is a small likelihood that they will get the disease and even if they get it that it will have serious consequences for them. A study published in June this year indicated that world-wide people's trust in Science ranged ashigh-18 percent, medium-54 percent, and low-14\%. The findings tend to indicate on an average the belief in scientific findings and observations has not found suitable footing in the 21 centuries. Therefore, building citizens trust on Science assumes significance at this juncture.

Differing Goals: People tend to have many different goals. For instance, wearing face mask is helpful in preventing infection spread from public health perspectives, but to some the same may pose individual inconvenience and certain degree of embarrassment for self-projection. At any given moment, some goals are more active than others. The active goals influence the actions one think are most appropriate to take. Those goals also influence how one interpret the information one encounter. Research on motivated reasoning finds that when people have a goal that is important to them, they interpret information they encounter in a way that is consistent with that goal. It is natural, then, to want the world to be amenable to the outcomes one wants. In such a scenario, situation-based management system, that may require involvement of many actors, need to be augmented by the administration.

\section{Conclusion}

In countries where education is not evenly spread or of unequal standard, as in India, the wearing of mask, maintaining social distance norms and following lockdown rules might have some psychological dimensions and problem of knowledge gaps, yet at this stage, community engagement at local level and coordinated efforts of providing key guidance and relevant information for pandemic business continuity plans forms the backbone of good governance.

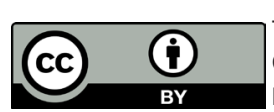

This work is licensed under Creative Commons Attribution 4.0 License DOI: 10.19080/GJAA.2020.11.555819

\section{Your next submission with Juniper Publishers will reach you the below assets}

- Quality Editorial service

- Swift Peer Review

- Reprints availability

- E-prints Service

- Manuscript Podcast for convenient understanding

- Global attainment for your research

- Manuscript accessibility in different formats

( Pdf, E-pub, Full Text, Audio)

- Unceasing customer service

Track the below URL for one-step submission

https://juniperpublishers.com/online-submission.php 